\title{
O Segundo Retôrno *
}

\author{
Vicente Marotta Rangel. \\ Catedrático de Direito Internacional Público. \\ na Faculaade de Direito da Universidade de- \\ São Paulo.
}

Dispõem as normas disciplinadoras da Faculdade de Direito da Universidade de São Paulo, que a Congregação outorgará o título de "Professor Emérito" ao catedrática aposentado cujos serviços ao magistério se reputarem de excepcional relevância.

E por entender que à nobre e elevada qualificação. fizeram jus as docências dos doutores Alexandre Corrêa, Alvino Lima, Antônio Ferreira de Almeida Júnior, Honório Monteiro, Jorge Americano, Lino de Morais Leme, Nicolau. Nazo e Vicente Ráo, julgou por bem que nesta solenidade lhes fôssem entregues os diplomas respectivos de "Professor Emérito".

Desejou-se imprimir, pois, ao encerramento do presente ano letivo, marca excepcional, tão conspícuos os destinatários da homenagem, tão significativa a cerimônia em que a Faculdade se reencontra, comovida e jubilosa.

Como sói acontecer em cada lar, ao término de dezembro, reunímo-nos também em família, irmanados pelo amor às tradições da Casa do Direito, atraídos pelo foco de esperança que ela encarna. Identifíca-nos, ademais, esta noite, indeclinável propósito, o de outorgar aos que a mereceram, a mais excelsa das jóias que o escrínio das Arcadas custodia e pode oferecer.

* Saudação aos Professôres Eméritos proferida a 21 de dezembro. de 1966, em sessão solene da Congregação. 
A quem por derradeiro se assentou em cátedra desta Faculdade, é que se deferiu o encargo de testemunhar, de público, o gáudio de que estamos possuídos e o alcance da homenagem que desejamos prestar. A desvanecedora missão, não nos seria possível recusá-la. Ao coração do discípulo e amigo, ela é grata e dir-se-ia càlidamente almejada; e ao espírito de quem é o menos credenciado, na ordem da precedência e dos méritos, subsiste o raro ensejo de rever, no conjunto, os lineamentos das trajetórias escarpadas e ascendentes da carreira universitária, para aferir, com admiração, os merecimentos de quem as transpôs, por inteiro, com tenacidade, ardor e talento.

Não confere ao mestre louros permanentes de vitória * brilho excepcional das aulas, nem o filão precioso das pesquisas, nem o cerne e a seiva das obras publicadas, nem o resultado feliz dos concursos públicos e perturbadores. Não basta. Importa mais. Importa que com o transcurso dos anos, se assente em definitivo o julgamento das gerações que, como vagas sucessivas, deixem escrito na areia dos tempos a sentença consagradora.

\section{Professôres Eméritos!}

Indaga o Talmud com o que se assemelha o professor e responde, com acêrto: "ao frasco que contenha ungüento aromático". "Aberto o frasco, o perfume se expande; fechado, o perfume desaparece". A melhor interpretação, porém, do autorizado livro hebraico não há de ser a restritiva e literal. Ainda que cessadas as aulas, os ensinamentos persistem, a inebriar com a fôrça e a beleza das verdades que irradiam.

Viestes de longe, longamente acalentando o sonho de pertencer a esta Casa, onde vos integrastes de início como alunos, vivendo a quadra rumorejante e dourada do inebriante e doce convívio acadêmico. Não resististes à tentação de franquear de novo os umbrais da Academia, e anos volvidos vos apresentastes como candidatos a postos do magistério. Não vos foi fácil nem imediata a reali- 
zação dêsse propósito. Exigiram-vos sacrifícios, preparação diligente e adequada, empenho tenaz. Catedráticos enfim por concurso de títulos e provas, honrastes, períodos letivos reiterados, a missão que ambicionastes receber $\mathrm{e}$ cumprir. Não esmorecestes na senda entrevista e palmilhada a passo e passo. Meditações, cursos, exegeses, debates, vivência dos problemas jurídicos e universitários, tudo foram meios para enriquecer o patrimônio das disciplinas e o cabedal de cultura dos estudantes. E se mais não pudestes realizar, nos estritos limites da docência, foi porque o rigor da lei vos fulminou com a compulsoriedade da aposentadoria. Mas tal o fulgor dos ensinamentos, a solidez da obra edificada, a incoercibilidade da vocação universitária, que hoje se opera a magia e o momento do segundo retôrno, aquêle que não mais depende da vontade dos eventuais postulantes senão do julgamento dos que permaneceram no exercício efetivo da cátedra. Julgamento êsse que tem por efeito vencer os imperativos da própria lei e nos confere duplo sentimento: o da alegria e o da honra. A alegria de vos ver com o direito a realizar cursos. E a honra de continuar convosco - preclaros mestre - nas reuniões da Congregação ou, eventualmente, em comissões universitárias, recebendo de vós, pois, diretamente, com mais freqüência, as benesses da vossa experiência, do vosso saber, da vossa palavra.

O côro dos juízos que cerca os vossos passos é, destarte, bem diverso daquele que circundava o retôrno à terra natal da personagem legendária descrita e cantada por IBSEn em seu drama poético formoso.

Depois de percorrer o mundo e de nele experimentar o sabor de tôdas as aventuras, Peer Gynt prosseguia em demanda do lugar de onde partira. Revia, sobressaltado, na paisagem escandinava, o moinho, os pinheirais, a torrente cristalina. Mas incomodaram-no as bolotas que, continuamente, lhe rolavam aos pés, impedindo-lhe a caminhada. "De que se trata?", indagava conturbado, e elas respondiam serem os pensamentos que Peer Gynt não 
houvera tido. Fôlhas secas lhe tombavam sôbre a fronte e diziam serem as palavras desconhecidas do velho mistério, as que Peer Gynt deixara de proferir. $\mathrm{E}$ as brisas que perpassavam murmuravam ser os cânticos inexprimidos, aquêles que a alma ressequida de Peer Gynt não soubera entoar no declínio suave de cada dia. E' as gotas de orvalho tombavam das árvores. Eram as lágrimas que a dureza do coração de Peer Gynt impedira de verter. E as palhas esparramadas no chão aduziam: "Somos os sonhos que morreram no caminho", os sonhos que a dúvida e a carência de fé do viandante houveram para sempre repelido.

As luzes que se esparramam nesta sala, a majestade dos candelabros, a rigidez hierática e rubra das cortinas pesadas, a sobranceria dos doutorais, a liturgia das becas, a presença amiga dos assistentes, discípulos e familiares, - tudo está a proclamar, ao revés, a fecundidade dos vossos sonhos, a beleza altissonante dos vossos cânticos, a permanência de vossas palavras, a firmeza de vossa fé, as emoções de vossa vida, a constante irradiação de vossos ensinamentos.

Em verdade, as galas desta noite murmuram aos ouvidos dos circunstantes os títulos de obras pensadas, escritas, realizadas, vigas mestras que sustentam o zimbório da cultura jurídica do país.

Mencione-se o nome de quem dentre vós primeiro ascendeu à cátedra, transcorridos quarenta anos, o de VICENTE RÁo, e as luzes da cerimônia põem em foco Direitos da Mulher Casada Sôbre o Produto de seu Trabalho; Posse dos Direitos Pessoais; O Direito e a Vida dos Direitos; Ato Jurídico. . Ao nome de Jorge Americano, elas relembram: Da Ação Pauliana; Do Abuso do Direito no Exercício da Demanda; Dos Direitos que se Exteriorizam pela Posse; Comentários ao Código de Processo Civil... À Menção de Honório Monteiro, as luzes clamam: Da MuIher Casada Comerciante; Dos Efeitos Juridicos da Sentença Declaratória de Falência sôbre o Contrato de Conta 
Corrente; Do Crédito Bancário Confirmado; Contrato Misto... Evoque-se Alexandre Correia, e elas sublinham: A Concepção Histórica do Direito; O Conselho de Jus Naturale, Gentium et Civile no Direito Romano; Manual de Direito Romano; Concepção Tomista do Direito Natural... Ao nome de Lino de Moraes Leme, as galas da noite aditam: Posse dos Direitos Pessoais; A Responsabilidade Civil fora do Contrato; O Erro do Direito em Matéria Civil; Direito Civil Comparado... Fale-se em Alvino Lima, e elas aduzem: Da Culpa ao Risco; O Direito de Retenção e o Possuidor de Má Fé; Do Fideicomisso nas Doações Inter-Vivos, no Direito Civil Brasileiro; A Fraude no Direito Civil.. Pronuncie-se o nome de Antônio Ferreira de Almeida Junior e elas apontam: $O$ Exame Médico Pré-Nupcial; Paternidade; As Provas Genéticas da Filiação; Lições de Medicina Legal... Diga-se enfim o nome de Nicolau Nazo e os fascínios da noite festiva acrescentam: Da Aplicação e da Prova do Direito Estrangeiro; Do Objeto e Método do Direito Internacional Privado; A Determinação do Domicílio no Direito Internacional Privado Brasileiro; A Decadência no Direito Civil Brasileiro...

Se auscultarmos as passadas dos viandantes dêsse segundo retôrno, notar-lhes-emos a similitude do ritmo e a fôrça idêntica da cadência. Nelas se poderia, porém, aferir distinções que, em verdade, seriam mais de pormenor e acidentais. $O$ que seria cabível dizer de pronto é que as referências às virtudes de um, por inteiro, aos demais hão de caber. Se nos fôsse dado compor o retrato psicológico e moral de cada qual, poderiamos invocar os adequados juizos que de Honório Monteiro fizera Spencer Vampré: "o espírito de justiça; a retidão dos conceitos; a elevação dos propósitos; e o acendrado amor a esta Casa gloriosa, e à pujante juventude que a habita".

As mesmas qualidades persistem e se desdobram, em todos vós, de sorte a influir benfazejamente no espírito 
dos professôres mais jovens e dos discípulos que, em cada turma, se renovam. Cultores dos valores transcendentais, timbrastes em não desvincular do culto da Justiça o do Bem e o do Belo. Tanto no apregoar como no praticar, é nisso também que vos aproximais e vos identificais. Há os que se dedicam, especialmente, à arte da pintura, como Jorge Americano; ou os que se afeiçoam à arte de Euterpe, como Nicolau Nazo, que foi professor do Conservatório Dramático e Musical. Certo é que todos sois igualmente estetas, exímios cultores da palavra escrita e falada. E o sois com clareza, sem embargo de poder parecer, ao desprevenido olhar do mundo, superficiais.

E nisto vos mantendes sábios e mestres. Da sabedoria longa e pacientemente constituída. Da mestria gradualmente formada e aprimorada. Alguns com vivência desde o magistério do curso primário, o iniciado em Santos, por Almeida Junior, ou em Serra Negra, por Lino Leme; outros com prática também no curso secundário ou colegial, como Alexandre Correia, lente de latim e grego em Ribeirão Preto; ou como Alvino Lima professor de matemática em Casa Branca...

Em verdade, como lembrou Nicolau Nazo, "para que a nobre função de ensinar não sofra solução de continuidade, não raro e, insensivelmente, os momentos de lazer são substituídos pela meditação do que se aprendeu, a fim de verificar a perfeita adequação dos princípios jurídicos à realidade social, quando não para estudar novos meios com o fim de mais fàcilmente serem êsses princípios assimilados por aquêles que se iniciam na linguagem do Direito". Ainda que circunscritos à meditação, não deixastes de viver a tentação de penetrar o âmago da realidade que nos circunda.

Por êsse motivo, se houve dentre vós quem preferisse permanecer recolhido ao gabinete de estudo, houve os que atenderam aos reclamos da vida pública. Aprimora-se a estrutura social tanto com o estudo e a meditação dos princípios que a norteiam como através da ação que os 
converte em realidade. Ação que atenda às necessidades vitais do homem e satisfaça aos reclamos das categorias sociais. Que preserve, ao menos, a educação, a saúde e a liberdade, os pilares da democracia, no dizer expressivo de Almeida Junior. Ministro da Justiça e das Relações Exteriores, eis Vicente Ráo. Ministro da Justiça e do Trabalho, Presidente da Câmara dos Deputados, o foi Honório Monteiro. À vida universitária, todos deram valiosa contribuição. Uns examinaram-na em minuciosa perspectiva histórica: Alexandre Correia e Lino Leme, para citar. Outros assumiram e ainda assumem encargos da mais alta responsabilidade, no plano federal e estadual de ensino: Almeida Junior e Honório Monteiro. Foi Jorge Americano reitor da Universidade de São Paulo. Alvino Lima e Honório Monteiro, diretores desta Faculdade. E do Conselho Universitário também participou Nicolau Nazo, representando os antigos alunos. Ao estudo e à prática da Universidade, no silêncio das bibliotecas ou no torvelinho da atividade política, todos deram igualmente o melhor de suas colaborações, e sem adstringi-las ao âmbito da vida nacional, ampliaram-nas também ao setor das relações internacionais de cujos certames têm participado, recebendo e oferecendo subsidios científicos do mais alto porte.

Ao encerrar acurado estudo sôbre a universidade medieval, referiu-se com propriedade Alexandre Correia ao nobre orgulho dos professôres de então, "quando de tôda a Europa acudiam estudantes cheios de entusiasmo a passar longos anos em Paris e Bolonha para lhes seguir as lições". Com o advento do Renascimento, evidenciou-se a modificação das instituições sociais e políticas européias e alteraram-se as próprias condições do estudo, as dos discípulos e as dos mestres. 0 fenômeno da crise universitária, acompanhado paralelamente pelo divórcio crescente entre os novos problemas e as formas clássicas do saber, passou a ser uma dolorosa constante dos tempos modernos, trazendo em conseqüência outro desajustamento: entre os 
que ensinam ou devem ensinar e os que estudam ou devem estudar. A continuidade da crise, conquanto alterada em alguns de seus aspectos secundários, ainda se delineia ao nosso olhar e ainda ecoa, nìtidamente, aos nossos ouvidos.

O desdobrar dessa crise, teve-o presente e o destacou enfàticamente, há mais de trinta anos, Jorge Americano, em seu discurso de posse na cátedra de direito civil. "Também o professor estuda hoje - assinalara - sob a pressão dos fatos sociais. Cabendo-lhe a responsabilidade de preparar o meio dirigente, é forçado a refazer o exame de suas noções básicas". Dois anos mais tarde, o mesmo tema é ferido por Lino Leme. "As lutas que hoje observamos indicam - escrevia - uma intensidade bem grande na ação das fôrças modificadoras, e a grande responsabilidade de nossos centros de cultura, em procurar a harmonia social. Os fundamentos da vida social foram abalados, e o mundo procura uma nova organização"

Como consegui-lo? Eis a indagação que persistiu, de forma obsessiva, implícita ou explìcitamente, em vossa mente, senhores professôres eméritos, e por certo ainda subsiste. Ela se mantém reiterada nas dobras dos escritos de todos vós. A resposta a destes, invocando a necessidade de estimular duas aptidões fundamentais: de um lado, a da sensibilidade para acompanhar o fluxo das mutações sociais; de outro lado, a da compreensão para sustentar os princípios básicos da vida em sociedade e da própria natureza humana. Uma e outra aptidão, aliás, a se completarem e a se exigirem mùtuamente. É que, como assinala com razão Maurice Bourouin, se, em certo sentido, a necessidade de estabilidade e a de movimento podem ser consideradas contraditórias, o movimento, na realidade das coisas, se torna "condição da própria estabilidade". $\mathrm{Ou}$, acrescentemos, o que não seria excessivo, a estabilidade, se torna "condição do próprio movimento". Donde, a ênfase que destes a êste núcleo fundamental de todo sistema jurídico, em função do qual se diluem e se transcendem as eventuais antinomias entre estabilidade e dina. 
mismo, entre ordem e movimento, entre fato social e norma jurídica. A saber, o núcleo fundamental que é a pessoa humana, em tôrno da qual se tem concentrado a preocupação de todos vós, eméritos professôres, e que motivou o cerne da resposta de Jorge Americano e Lino Leme às indagações que fizeram. Sirvam de exemplo as palavras de Alvino Lima aos bacharéis de 1957, que paraninfara, indagando-lhes se "seria possível reduzir a criatura humana a um fantoche de cera, que os dedos de um tirano, ou de seus capatazes, apaniguados ou servos, plasmam a seu talante e soltam a correr pela vida, como êstes bonecos de corda, que fazem a delícia das crianças". Outrossim, quando cuidara Vrcente Ráo de fixar os conceitos fundamentais que guiariam a exposição da obra que dedicou a esta Faculdade, entendeu assim, igualmente, fixá-los: “o da unidade fundamental e substancial do conceito do Direito e o de sua construção sistemática e científica erguida sôbre a base dos direitos inerentes à personalidade humana".

Pertencendo a uma geração que teve de viver e acompanhar os embates da primeira guerra mundial, acompanhastes a transformação do mundo, e apesar dela, e mesmo por causa dela, mantivestes fé no direito e na justiça. A modificação não cessou e não cessará. Acentua-se em escala mundial e em nossa pátria, acelerada pelas vicissitudes da segunda guerra mundial, e sobretudo pelo torvelinho da era termo-nuclear e inter-planetária que estamos intensamente a viver.

Inquietam-nos as sombras que conturbam a paisagem internacional, o desassossêgo dos espíritos, o ódio acicateado, os gemidos de dor, as súplicas de fome, o rôlo de fumaça que irrompe dos bombardeios, a procura da guerra, a sistemática recusa em aceitar os meios pacíficos de solução de litígios, em buscá-los, em cumpri-los.

Conturba-nos a visão de nossa pátria, assolada, dividida, hesitante nos rumos a trilhar. Afligem-nos soluções 
de cúpula, que ora se propõem trajadas de mantos constitucionais, nascidas de grupos restritos e fechados, apartadas da contribuição dos viveiros políticos e jurídicos do país, dos quais esta Faculdade, com a ufania de sua tradição gloriosa e com a pujante contribuição de sua vida cultural presente, se esmera em participar. Entristecemnos as proposições que entram em conflito com os reclamos mais profundos da nação, máxime as que desconheçam ou hostilizem os direitos fundamentais da pessoa humana.

Restam-nos contudo, mestres agraciados pelo prêmio mais dignificante desta Faculdade, o consôlo e a honra de vossa presença em nosso meio, e a esperança de ainda mais contar convosco, com a vossa experiência, com o vosso saber. Resta-nos, enfim, a alegria que é imensa de repetir convosco, em uníssono, as afirmações do ato de fé que um dentre vós escreveu, e vale como se todos nós, meus senhores, professôres e alunos, houvéramos escrito: "Creio no Direito. Creio nos seus cultores, Creio numa execução honesta do Direito. Creio que a inteligência dos jovens é capaz de discernir a Verdade. Creio, enfim, que duradouramente há de se impor a fôrça da Verdade".

Professôres Eméritos:- A êste jubiloso e final reencontro, sêde benvindos! 